\title{
.STRATEGI PEMBANGUNAN PERIKANAN BUDIDAYA DI KABUPATEN KAMPAR PROVINSI RIAU
}

\section{STRATEGY OF AQUACULTURE DEVELOPMENT IN KAMPAR REGENCY OF RIAU PROVINCE}

\author{
Yusrizal $^{1}$, Darwis ${ }^{1}$, Zulkarnain Umar ${ }^{1}$ \\ 1 Kekhususan Agribisnis Perikanan Magister Ilmu Kelautan, Fakultas Perikanan dan Kelautan, \\ Universitas Riau, Jl. HR Soebrantas Km 12,5 Simpang Baru, Panam-Pekanbaru Indonsia 28293 \\ Correspondence Author :yusriZulnuzula@gmail.com
}

A R T I CLE IN FO

Submitted: 25 April 2018

Revised : 10 Mei 2018

Approved: 05 Juni 2018

\section{Kata kunci:}

Implementation,

Synergy

Strategy

\begin{abstract}
The purpose of this research is to analyze the implementation of fishery aquaculture development program, synergy development of aquaculture culture and to describe strategy of synergy of development of aquaculture fishery in Kampar regency._The research method used is field survey method with interview and questionnaire. The results showed that the implementation of the development of aquaculture reached $55.89 \%$ of the realization of the budget of Rp 57.595 billion, with the activity of 11 (eleven) activities / projects, in synergy fisheries development there are two aspects that must be synergized, management aspects (planning, organizing, controlling) and aspects of human resources, (regulation, budgeting, aperature resources), SWOT analysis shows that Kampar Regency has some power to exploit the big opportunities, for the strategy of synerginity of aquaculture development in the first quadrant (one) the government can utilize SO (Strengths-Opportunities).
\end{abstract}

Abstrak

Penelitian ini bertujuan untuk menganalisis implementasi program pembangunan perikanan budidaya, sinerginitas pembangunan perikanan budidaya dan mendesaian strategi pembanguan perikanan budidaya di Kabupaten Kampar. Metode penelitian yang digunakan adalah metode Survey lapangan dengan wawancara dan kuisioner. Hasil penelitian menunjukkan bahwa implementasi pembangunan perikanan budidaya mencapai 55,89 \% realisasi anggaran Rp 57,595 Miliyar, dengan jumlah kegiatan 11 (sebelas) kegiatan/proyek, hasil analisis sinergitas pembangunan perikanan budidaya dikabupaten Kampar, sinerginitas faktor-faktor dalam menunjang pembangunan perikanan disebabkan oleh 3 (tiga) faktor, faktor sumberdaya lahan dengan kontribusi $50 \%$, Ekonomi $\quad 16,7 \%$ sosial $8.00 \%$. sedangkan sinergitas stakeholder dalam pencapain tujuan pembangunan perikanan disebabkan peranan pemerintah $50.00 \%$, masyarakat $33.33 \%$, swasta $16.7 \%$. hasil analisis SWOT menunjukkan kabupaten Kampar mempunyai beberapa kekuatan untuk memanfaatkan peluang yang masih besar, dalam strategi sinerginitas pembangunan perikanan budidaya dikabupaten Kampar berada pada kuadran I (satu) pemerintah bisa memanfaatkan strategi S-O ( Strengths- Opportunities). 
PENDAHULUAN

Perubahan lingkungan institusi atau organisasi publik pada dekade terakhir dihadapkan pada berbagai perubahan, gejolak, dan kemajuan yang sering kali sulit diprediksi, baik karena pergolakan maupun ketidakpastian yang di alami. Kondisi ini membutuhkan antisipasi dini, yang sebelumnya belum pernah terjadi, sehingga institusi atau organisasi mau tidak mau (inevitable) harus melakukan tiga hal sebagai berikut (Bryson, 2008).

Konsep strategi selalu memberi perhatian serius terhadap perumusan tujuan dan sasaran organisasi, faktorfaktor yang menjadi kekuatan serta kelemahannya, serta peluang dan tantangan yang senantiasa dihadapi oleh setiap organisasi. Analisis mengenai faktor ini sangat berguna dalam merumuskan alternatif yang akan memudahkan para pengambil keputusan tertinggi dalam setiap organisasi memilih alternatif terbaik (Salusu, 2006).

Dalam pengembangan perikanan di Kabupaten Kampar, peran dari pengambil kebijakan merupakan salah satu hal yang berpengaruh penting, dimana kebijakan yang di ambil akan mendukung program yang sudah di rancang. Baik dari internal maupun eksternal, maka diperlukan suatu strategi yang bisa menciptakan suatu sinergitas. Dilihat dari realita di lapangan masih terjadi kesenjangan antara pemerintah, pelaku usaha, dan juga belum adanya keterpaduan antara suatu lembaga dengan lembaga lainnya, sehingga program yang dijalankan secara sendiri-sendiri.

Selain itu terbatasnya usaha diversifikasi produk, pemasaran, tingginya harga pakan, masih kurangnya sarana dan sarana penunjang perikanan. Kemampuan modal yang dimiliki oleh pembudidaya perikanan dan pengolah ikan masih kecil sehingga sangat sulit untuk mengembangkan usaha perikanan. Kesenjangan antara instansi, serta tarik ulur kepentingan, yang memperjuangkan kepentingan masing-masing.
Berdasarkan dari data penelitian tersebut, maka penelitian ini dilakukan untuk mengetahui bagaimana program dan strategi yang dijalankan bisa mencapai sasaran. Tujuan dari penelitian ini adalah untuk Mengetahui dan menganalisis implementasi program pembangunan perikanan budidya yang dilaksanakan Mengetahui dan menganalisis sinergitas pembangunan perikanan budidaya di Kabupaten Kampar, Mendesain strategi pembangunan perikanan budidaya di Kabupaten Kampar. Sedangkan manfaat penelitian ini dapat memberikan pandagan pemikiran dalam upaya memperkaya ilmu pengetahuan dalam bidang perikanan budidaya, khususnya dalam bidang penguatan strategi

\section{METODE PENELITIAN}

Metode penelitian yang digunakan adalah metode Survey lapangan dengan wawancara dan kuisioner, yang dimulai dari tahap awal survey lapangan, untuk menentukan kondisi awal objek penelitian, kemudian pengumpulan data, serta mempersiapkan instrument yang akan digunakan di lapangan. Setelah semua data terkumpul dilanjutkan dengan pengelolaan data penelitian.

\section{Pengumpulan Data}

Pengumpulan data dilakukan melalui metode wawancara bertahap dan mendalam (in-dept interview), observasi partisipasi (participant observer), dan diskusi terfokus atau focus group discussion (FGD). Data yang dikumpulkan digolongkan dalam data primer dan data sekunder. Data primer difokuskan dengan observasi dan wawancara terhadap pelaku usaha perikanan, instansi terkait, dan masyarakat. Sedangkan data sekunder diperoleh dari instansi terkait.

\section{Penentuan Responden}

Penentuan responden dilakukan dengan mengambil beberapa tokoh formal dan informal, untuk dilakukan wawancara 
$\begin{array}{cccc}\text { secara } & \text { terstruktur } & \text { (kuisioner) } & \text { kepada } \\ \text { pelaku } & \text { usaha } & \text { perikanan, } & \text { tokah }\end{array}$ masyarakat, dan instansi pemerintah. yang diperlukan, di antaranya Dinas Perikanan Kabupaten Kampar, Bidang Perikanan Budidaya, terdiri dari Seksi Budidaya Perikanan, UPTD BBI Lokal Bangkinang, bertugas sebagai unsur penunjang dalam bidang perbenihan perikanan, Kelompok Jabatan Fungsional; bertugas sebagai tenaga fungsional penyuluh di lapangan, Badan Perencanaan Daerah (Bapeda) kabupaten Kampar, Tokoh masyarakat yang berperan dalam kemajuan perikanan, petani pem-budidaya yang ada diwilayah Objek Penelitian

\section{Metode Analisis}

\section{Analisis Implimentasi Program Pembangunan Perikanan Budidaya di Kabupaten Kampar}

Implimentasi

program

kegiatan/proyek dalam pengembangan budidaya perikanan pada dinas perikanan Kabupaten Kampar harus ada tolak ukur penentu dalam mengimplementasikan program kegitan/proyek. Tolak ukur dan penentu dalam implimentasi program kegiatan dalam bidang pengembangan budidaya perikanan di Kabupaten Kampar dilakukan dengan metode deskriptif, Kuantitatif dan kualitatif . Analisis diskriptif dan kualitatif digunakan untuk mengetahui Kebijakan Pembangunan Perikanan Budidaya di Kabupaten Kampar. Analisa ini untuk mengidentifikasi dan menjelaskan kebijakan Pemerintah dalam Implementasi pembangunan Budidaya Perikanan di Kabupaten, tingkat keberhasilan program/kegiatan bidang perikanan budidaya, serta dampaknya terhadap masyarakat dalam peningkatan usaha dan produksi perikanan budidaya di Kabupaten Kampar. . Pada tahun 2003 baru diproduksi sebesra 0,3 juta ( 5,5\%) hasil-hasil perikanan di perairan umum melalui usaha budidaya air tawar (Ghufron, 2015)

\section{Analisis Sinergitas Pembangunan Perikanan Budidaya di Kabupaten Kampar}

Dalam menganalisis Sinergitas Pembangunan perikanan budidaya di Kabupaten Kampar dilakukan kajian terhadap Strategi sinergisitas dan sensitivitas antar faktor-faktor yang berkontribusi dalam Pembangunan Perikanan Budidaya di Kabupaten Kampar. Kajian ini dapat dilakukan dengan identifikasi faktor-faktor apa saja yang berkontribusi dalam pencapaian tujuan (goals) kebijakan pembangunan perikanan budidaya di Kabupaten Kampar.

\section{Analisis Strategi Pembangunan Perikanan Budidaya Kabupaten Kampar}

Analisis Strategi Pembangunan Perikanan Budidaya dalam menentukan Strategi pembangunan perikanan budidaya di dilakukan dengan analisi SWOT, Menurut Rangkuti (2006) analisis SWOT (Strength, Weakness, Opportunity, Threat) merupakan identifikasi berbagai faktor secara sistematis untuk menentukan prioritas strategi alternatif pengembangan yang paling tepat dilaksanakan. Analisis ini didasarkan pada faktor internal dan eksternal untuk memaksimalkan kekuatan dan peluang, serta dapat meminimalkan kelemahan dan ancaman.

HASIL DAN PEMBAHASAN

Implementasi Program Pembangunan Perikanan Budidaya di Kabupaten Kampar Tahun 2012-2016

Implementasi program

pembangunan pengembangan budidaya perikanan di Kabupaten Kampar, berdasarkan rencana strategis (RENSTRA) Dinas Perikanan Kabupaten Kampar dapat diuraikan program pengembangan budidaya perikanan sebagai mana tersaji pada pada (Tabel 1). 
Tabel 1. Program dan Kegiatan Dalam Bidang Budidaya Perikanan Dinas Perikanan Kampar Tahun 2012 - 2016

NO.

\section{KEGIATAN}

\begin{tabular}{|c|c|}
\hline A. & $\begin{array}{l}\text { PROGRAM PENGEMBANGAN } \\
\text { BUDIDAYA PERIKANAN }\end{array}$ \\
\hline 1 & $\begin{array}{l}\text { Penumbuhan dan Pengembangan Usaha } \\
\text { Perbenihan }\end{array}$ \\
\hline 2 & $\begin{array}{l}\text { Penumbuhan dan Pengembangan } \\
\text { Perikanan Budidaya Kolam }\end{array}$ \\
\hline 3 & $\begin{array}{l}\text { Penumbuhan dan Pengembangan } \\
\text { Perikanan Budidaya Keramba }\end{array}$ \\
\hline 4 & $\begin{array}{l}\text { Pendampingan pada Kelompok Tani } \\
\text { Pembudidaya Ikan }\end{array}$ \\
\hline 5 & $\begin{array}{l}\text { Pengembangan sarana dan prasarana } \\
\text { perikanan budidaya prasarana perikanan } \\
\text { budidaya (DAK) }\end{array}$ \\
\hline 6 & $\begin{array}{l}\text { Dukungan menejemen \& pelaksanaan } \\
\text { Pengembangan sarana prasarana } \\
\text { perikanan budidaya }\end{array}$ \\
\hline 7 & $\begin{array}{l}\text { Penumbuhan dan Pengembangan } \\
\text { Usahan Pembuatan pakan ikan. }\end{array}$ \\
\hline 8 & $\begin{array}{l}\text { Optimalisasi Balai Benih Ikan (BBI) } \\
\text { Lokal }\end{array}$ \\
\hline 9 & $\begin{array}{l}\text { Optimalisasi Laboratorium Penyakit } \\
\text { Ikan dan Kualitas Air. }\end{array}$ \\
\hline 10 & $\begin{array}{l}\text { Pembinaan penyaluran Dana bergulir } \\
\text { ekonomi kerakyatan }\end{array}$ \\
\hline 11 & $\begin{array}{l}\text { Penerapan Inovasi dan teknologi tepat } \\
\text { guna perikanan. }\end{array}$ \\
\hline
\end{tabular}

Sumber : Rencana Strategis Dinasi Perikanan Kampar 2012 - 2016

Pelaksanaan kegiatan yang sudah diusulkan pengerjaannya berdasarkan skala prioritas berdasarkan kebutuhan yang mendukung tercapainya Visi dan Misi Dinas Perikanan Kabupaten Kampar yang dituangkan kedalam Rencana Strategis (RENSTRA) Dinas Perikanan Kampar. Guna mewujudkan Visi pemerintah Kabupaten Kampar, maka melalui Misi yang ke 3 (tiga) Dinas Perikanan kabupaten Kampar mengembangkan potensi ekonomi kerakyatan yang kokoh, kuat dan berdaya saing. Pengembangan potensi ekonomi kerakyatan ini bisa di wujudkan melalui program pengembangan Budidya Perikanan yang ada di Kabupaten Kampar. Untuk mengoptimalkan potensi yang ada maka Dinas Perikanan Kabupaten Kampar melalui bidang pengembangan budidaya Perikanan menyusun 11 (sebelas) kegiatan/proyek yang dimasukkan kedalam Rencana Strategis (RENSTRA) yang di anggarkan setiap tahunnya sesuai dengan kemampuan keuangan daerah. Realisasi dan pelaksanaan kegitan yang sudah direncanakan dalam Rencana Strategis (RENSTRA) akan dilaksankan selama waktu 5 (lima) tahun anggaran (20122016).

Untuk mengetahui realisasi kegiatan/proyek dalam bidang pengembangan budidaya perikanan, maka dilakukan pengumpulan dan pengolahan terhadap data anggaran kegiatan dalam pengembangan budidaya perikanan di Dinas Perikanan Kabupaten Kampar selama kurun waktu 2012 - 2016. Indikator keberhasilan kegiatan tidak bisa dilihat dari Laporan Akuntabilitas Kinerja Pemerintah (LAKIP) saja, akan tetapi harus juga di lihat dari realisasi dilapangan dengan melibatkan masyarakat sebagai imbas dari realisasi kegiatan, Hasil pengumpulan dan pengolahan data anggaran dan kegiatan selama 5 (lima) tahun anggaran (2012-2016). Dalam melihat realisasi kegiatan berpedoman kepada Indikator Capaian awal yang sudah ditetapkan dalam Rencana Strategis (RENSTRA) yang dituangkan kedalam program dan diwujudkan dalam kegiatan/proyek setiap tahunnya. Realisasi dan implemenasi kegiatan dalam pengembangan budidaya perikanan di Kabupaten Kampar selama 5 (lima) tahun anggaran dapat dilihat pada lampiran 1 (satu). Dari data lampiran 1 (satu) yang merupakan realisasi dan implementasi program dalam bidang pengembangan budidaya perikanan pada Dinas Perikanan Kabupaten Kampar selama 5 (lima) tahun anggaran mempunyain 11 (sebelas) kegiatan/proyek yang dituangkan kedalam Rencana Strategis (RENSTRA) Dinas Perikanan kabupaten Kampar, dan akan diuraikan implementasi serta realisasi nya selama 5 (lima) tahun kegiatan berjalan secara satu persatu sesuai dengan kegiatan yang sudah direncanakan. 


\section{Penumbuhan dan Pengembangan Usaha Perbenihan}

Kegiatan penumbuhan dan pengembangan usaha perbenihan merupakan kegiatan/proyek yang pertama yang terdapat dalam program pengembangan Budidaya perikanan. Dalam implementasi kegitan/proyek Penumbuhan dan Pengembangan Usaha Perbenihan direncanakan 150 Juta/tahun dengan jumlah kegiatan 10 sasaran/tahun, dari data yang dikumpulkan peneliti yang terdapat dalam Laporan Akuntabilitas Kinerja Pemerintah (LAKIP) pada Dinas Perikanan Kabupaten Kampar kegiatan Penumbuhan dan Pengembangan Usaha Perbenihan tidak bisa diwujudkan setiap tahunnya, hal ini dikarenakan keterbatasan anggaran dan skala prioritas kegiatan. Sebagai mana terdapat pada lampiran 1 (satu), pada tahun-tahun tertentu kegiatan ini mendapatkan alokasi lebih dari yang direncanakan seperti pada tahun 2013 mendapatkan anggaran Rp 509 juta dengan jumlah kegiatan 10 jumlah sasaran dengan persentase (\%) realisasi $3.39 \%$. Kemudian pada tahun 2015 dan 2016 juga mendapatkan anggaran dengan jumlah yang berbeda-beda. Total keseluruhan anggaran yang di cairkan selama 5 (lima) tahun anggaran berjumlah 1.170 Miliar Rupiah dengan jumlah sasaran 196 sasaran dengan persentase (\%) $9,20 \%$.

\section{Penumbuhan dan Pengembangan Perikanan Budidaya Kolam.}

Dari hasil observasi lapangan penyaluran bantuan ini harus melalui tahapan dan kriteria yang sudah di tetapkan oleh pemerintah Kabupaten Kampar, tidak semua desa bisa mendapatkannya, akan tetapi desa-desa yang mendapatkannya berdasarkan perivikasi yang sudah dianggap layak dan memenuhi ketentuan yang diberikan bantuan, salah satunya syarat adalah mempunyai sertifikat kelayakan usaha dalam budidaya perikanan, yang dikeluarkan oleh Dinas perikanan melalui P4S. Penyaluran bantuan baik pakan dan bibit di serahkan kepada kelompok yang sudah di bentuk dan mempunyai anggota 10 (sepuluh) orang tiap kelompoknya. Realisasi bantuan ini di rasakan besar manfaatnya bagi masyarakat, seperti yang disampaikan arison penerima bantuan desa Koto Tuo Kecamatan XIII Koto Kampar. Salah satu kelemahan masyarakat dalam usaha perikanan adalah kurangnya modal untuk pembelian pakan, namun dengan adanya bantuan bibit dan pakan merupakan jawaban untuk mengatasi permasalahan yang dihadapi oleh masyarakat. Gambar 1.

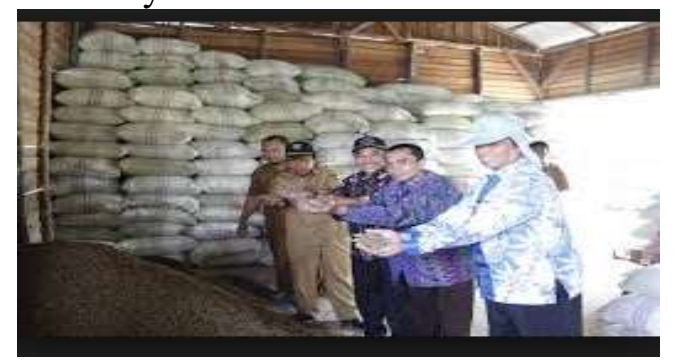

Gambar 1. Kolam Budidaya Dan Pakan Bantuan Dinas Perikanan Kampar

\section{Penumbuhan dan Pengembangan Budidaya Keramba.}

Alokasi anggaran tertinggi diperoleh tahun 2015 sebesar Rp. 1,055 milyar yang dapat memproduksi budidaya ikan keramba sebanyak $27.814 \mathrm{~kg}$ (27,8 ton). Pengembangan budidaya keramba ini terdapat disepanjang aliran sungai Kampar dan juga di waduk PLTA Koto Panjang. Dalam Pengembangan budidaya keramba ini Dinas Perikanan memberikan bantuan dalam bentuk pakan, dan juga benih baik kepada kelompok maupun individu. Data yang di dapat total anggran yang di salurkan untuk kegiatan ini sebersar 2.787 Miliyar rupiah dengan jumlah penerima bantuan 77 kelompok dengan persentase (\%) $3.87 \%$. Dibandingkan dengan Pengembangan Budidaya di kolam penerima bantuan dalam bentuk budidaya Kerambah jauh lebih sedikit, hasil wawancra dengan Kadis Perikanan Bapak Ir.H Usman Amin hal ini dikarenakan salah satunya pada 
kegiatan Budidaya Keramba resiko lebih tinggi di banding dengan budidaya di kolam.

Pembinaan ekonomi kerakyatan ini ditujukan di semua wilayah Kabupaten Kampar, dengan dibentuknya Koperasi Mitra Mandiri disetiap kecamatan, dan di samping itu adanya berupa bantuan lansung kepada masyarakta yang di berikan melalui Kelompok Usaha Bersama (KUB) baik berupa Bantuan benih, dan pakan. Hasil kebijakan ini memberikan dampak yang positif bagi perikanan Kampar terbukti dengan banyaknya Rumah Tangga Perikanan (RTP), dari data yang di dapat jumlah rumah tangga khususnya Budidaya Keramba sebesar 2.196 RTP atau 15.53\% dengan jenis komoditas antara lain Ikan Patin, Nila, Mas, Jelawat dan Lele. Di bawah ini merupakan salah satu contoh kegiatan keramba yang di kembangkan di Kabupaten Kampar (Gambar 2)

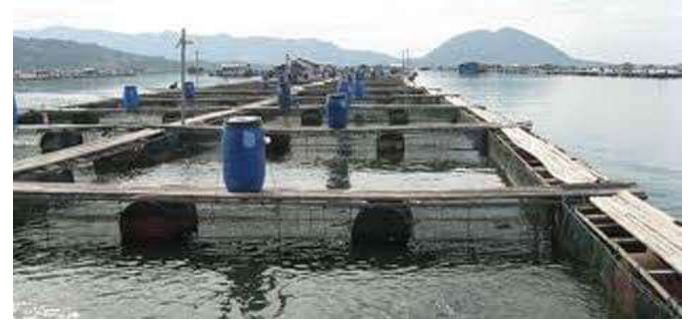

Gambar 2. Kegiatan Budidaya Keramba di Kabupaten Kampar

Analisis Sinergitas Pembangunan Perikanan Budidaya Di Kabupaten Kampar

Sinergisitas Faktor-faktor dalam Pencapaian Tujuan Pembangunan Budidaya Perikanan di Kabupaten Kampar

Dalam menentukan faktor-faktor yang mendorong dan mendukung pembangunan perikanan budidaya di Kabupaten Kampar maka dilakukan pengumpulan pendapat para stakeholders dan dianalisis dengan Analitical Hierarchy Proces (AHP) dengan menggunakan Sofware Expert Choice 9.0. Hasil kajian menunjukkan bahwa pembangunan perikanan budidaya di Kabupaten Kampar disebabkan oleh 3 (tiga) faktor :Faktor pertama Sumberdaya Lingkungan atau lahan budidaya dengan nilai bobot $50,00 \%$. Tingginya bobot faktor lingkungan ini dalam menentukan tujuan pembangunan budidaya perikanan disebabkan oleh faktor kesesuaian lahan atau kualitas lahan budidaya dengan nilai bobot $24.00 \%$, luas lahan mencukupi atau belum mencukupi memiliki bobot dukungan $16.00 \%$, faktor tata cara pengolahan lahan memiliki nilai bobot
$12.00 \%$, status kepemilikan lahan dalam arti kata lahan milik sendiri memiliki bobot nilai $8,00 \%$.Selain itu, yang berkontribusi terhadap peran Sumberdaya Lingkungan adalah tata kelola air yang baik memberikan kontribusi dengan nilai bobot $6.00 \%$.

Faktor kedua yang menyebabkan peningkatan pembangunan perikanan budidaya di Kabupaten Kampar adalah faktor Sumberdaya Ekonomi. Faktor ekonomi memiliki kontribusi dengan nilai bobot $16.7 \%$. Peranan faktor ekonomi ini dalam menentukan tujuan pembangunan budidaya perikanan disebabkan oleh faktor permodalan dalam arti kata modal sendiri memiliki nilai bobot $12.00 \%$. faktor sarana produksi keberadaan pakan atau pelet memiliki nilai bobot $8.00 \%$. Selain itu, faktor benih yang baik memberikan kontribusi dengan nilai bobot $6.00 \%$

Faktor ketiga yang menyebabkan terjadinya peningkatan pembangunan perikanan budidaya di Kabupaten Kampar adalah faktor Sumberdaya Sosial. Sumberdaya sosial yang memberikan kontribusi dukungan bagi peningkatan pembangunan perikanan budidaya adalah 
faktor pendidikan formal petani ikan dengan nilai bobot $8.00 \%$

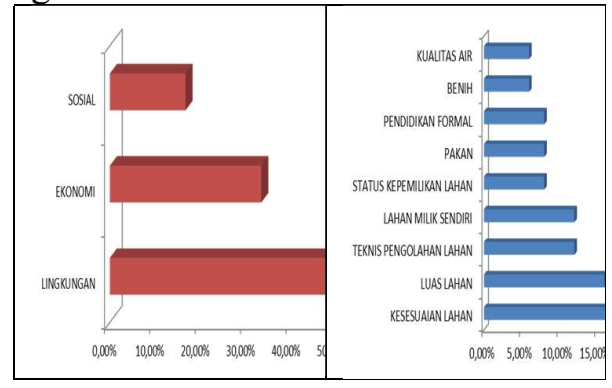

Sumber : Expert Choice 9.0

Gambar 3. Diagram batang nilai bobot faktor-faktor yang berperan dalam sinergitas pembangunan perikanan budidaya di Kabupaten Kampar.

\section{Sinergitas Stakeholder dalam Pencapaian Tujuan Pembangunan Budidaya Perikanan di Kabupaten Kampar}

Dalam menentukan priorietas peran stakeholders dalam Pembangunan Perikanan Budidaya di Kabupaten Kampar, maka dilakukan pengumpulan pendapat para stakeholders dan dianalisis dengan Analitical Hierarchy Proces (AHP) dengan menggunakan Sofware Expert Choice.Hasil kajian menunjukkan bahwa dalam Pembangunan Perikanan Budidaya di Kabupaten Kampar, bahwa peran pemerintah memiliki bobot yang paling tinggi yaitu sebesar 50,00\%, disusul peran masyarakat sebesar 33,3\% dan Swasta 16,7\%. Peran pemerintah yang tinggi di sini terutama pada pemerintah Kabupaten sebesar 25,0\%, Pusat $16,7 \%$, dan sementara itu Pemprov $8,3 \%$. Tingginya peran pemerintah kabupaten dalam Pembangunan Perikanan Budidaya di Kabupaten Kampar sangatlah logis, hal ini sejalan amanat UU No 22/1999 tentang otonomi daerah dimana kewenangan di bidang pembangunan sangat ditentukan oleh daerah itu sendiri, termasuk dalam hal ini kewenangan pemerintah daerah dalam menentukan arah kebijakan pembangunan perikanan. Faktor kedua yang memiliki peranan dalam Pembangunan Perikanan Budidaya di Kabupaten Kampar adalah masyarakat.
Komponen masyarakat yang memiliki proporsi terbesar dalam Pembangunan Perikanan Budidaya di Kabupaten Kampar adalah kelompok sebesar 16\%, disusul oleh peran perorangan sebesar $8.8 \%$, dan LSM 4.9\%. Tingginya peranan masyarakat terhadap Pembangunan Perikanan Budidaya disebabkan peranan Kelompok Tani Perikanan memiliki bobot yang cukup tinggi $(15,39 \%)$, peranan RT/RW ini mendorong masyarakat dalam mengembangkan usaha perikanan budidaya atau kolam memiliki kontribusi peranan sebesar $10,26 \%$.

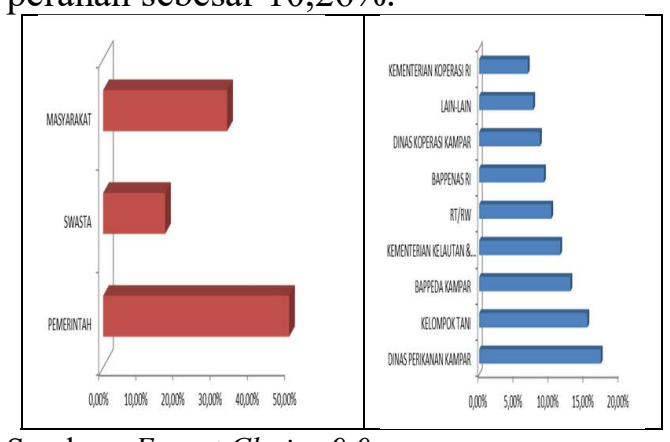

Sumber : Expert Choice 9.0

Gambar 4. Diagram Batang Nilai Bobot Stakeholder yang berperan dalam Sinergitas Pembangunan Perikanan Budidaya di Kabupaten Kampar.

Analisis sinergisitas peran stakeholders dalam Pembangunan Perikanan Budidaya di Kabupaten Kampar

\section{Simulasi Sinergisitas Peran Pemerintah dinaikkan $10 \%$}

Hasil analisis sinergisitas, apabila peran pemerintah dinaikkan $10 \%$ maka peran masyarakat mengalami penurunan dari $33.33 \%$ menjadi $26.66 \%$. Sedangkan swasta juga mengalami penurunan dari 16,67\% menjadi $13.33 \%$. Peningkatan peran pemerintah terjadi karena adanya peningkatan peran Dinas Perikanan Kabupaten Kampar dari 17.31\% menjadi 19.48\%, Badan Perencanaan Pembangunan Daerah Kampar dari $12.98 \%$ menjadi $14.61 \%$, Kementerian Kelautan Perikanan RI dari 11.54\% menjadi $13.00 \%$, Badan Perencanaan 
Pembangunan Nasional RI dari 9.23\% menjadi $10.39 \%$, Dinas Koperasi Kabupaten Kampar dari 8,65\% menjadi 9.74\%, dan Kementerian Koperasi RI dari $6.92 \%$ menjadi $7.79 \%$

Secara parsial peranan Dinas Perikanan Kabupaten Kampar menduduki proporsi paling tinggi sebesar $17.31 \%$, Kelompok tani $15.39 \%$, Badan Perencanaan Pembangunan Daerah Kampar sebesar $12.98 \%$, Kementerian Kelautan Perikanan RI sebesar 11.54\%, RT/RW sebesar $10.26 \%$, dan Badan Perencanaan Pembangunan Nasional RI sebesar 9.23\%, Dinas Koperasi Kabupaten Kampar 8.66\%. Kondisi ini menunjukan bahwa dalam pembangunan perikanan budidaya di Kabupaten Kampar secara umum upaya peranan pemerintah harus ditingkatkan.

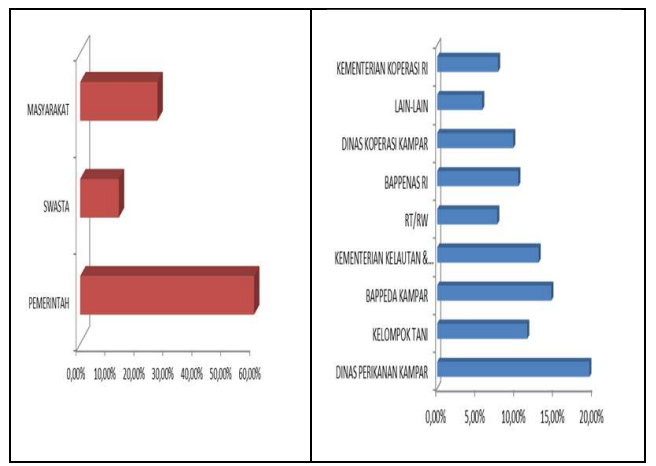

Sumber : Expert Choice 9.0

Gambar 5. Hasil Analisis Peran Pemerintah dinaikkan $10 \%$ dan sensitifitasnya terhadap peran stakeholder lain $19.48 \%$

Berdasarkan simulasi sinergitas dalam pembangunan perikanan budidaya di Kabupaten Kampar bahwa dengan peningkatan peranan pemerintah $10 \%$ dalam pembangunan perikanan budidaya mampu memberikan kontribusi yang efektif terhadap penurunan peranan masyarakat dan swasta, dari $33.33 \%$ menjadi $26.65 \%$, turun $6.68 \%$, dimana penurunan peranan masyarakat ini bisa digantikan oleh peran pemerintah dengan berbagai program dan kegiatan, sehingga apa yang menjadi kelemahan dari masyarakat bisa di perankan oleh pemerintah.

\section{Simulasi Sinergitas Peran Pemerintah Diturunkan 10\% \\ Hasil analisis sinergisitas} menunjukan apabila peranan pemerintah diturunkan $10 \%$ maka peranan masyarakat mengalami peningkatan dari $33.3 \%$ menjadi $39.90 \%$, dan peranan swasta dari $16.66 \%$ menjadi $19.95 \%$. Peranan masyarakat ini terjadi akibat adanya peningkatan peranan Kelompok Tani Ikan dari $15,39 \%$ menjadi $19.72 \%$, Pengurus RT/RW dari $10.26 \%$ menjadi $13.14 \%$, Sedangkan peningkatan peran swasta tidak terdeteksi dalam simulasi ini karena kontribusinya sangat rendah dan dibawah 10 (sepuluh).

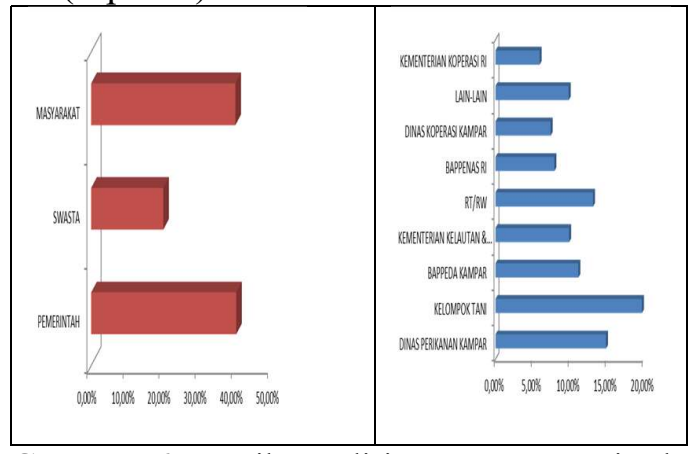

Gambar 6. Hasil Analisis Peran Pemerintah diturunkan $10 \%$ dan sensitifitasnya terhadap peran stakeholder lain. Sumber : Expert Choice 9.0

\section{Simulasi Peran Masyarakat dinaikkan} $10 \%$

Hasil analisis sensitivitas, apabila peran masyarakat dinaikkan $10 \%$ maka peran Pemerintah mengalami penurunan dari $50.00 \%$ menjadi $42,6 \%$. Sedangkan Swasta mengalami penurunan dari $16,67 \%$ menjadi $14.20 \%$. Penurunan peran pemerintah terjadi karena adanya penurunan peran Dinas Perikanan Kabupaten Kampar dari $17.31 \%$ menjadi 14.75\%, Badan Perencanaan Pembangunan Daerah Kabupaten Kampar dari $\quad 12,98 \%$ menjadi $11.06 \%$, Kementerian Kelautan dan Perikanan RI dari $11,54 \%$ menjadi 9,83\%, Badan Perencanaan Pembangunan Nasional RI dari $9.23 \%$ menjadi $7.86 \%$, Dinas Koperasi Kabupaten Kampar dari 8,65.1\% menjadi $7.37 \%$, dan Kementerian 
Koperasi dan UKM RI dari 6,92\% menjadi $5,90 \%$

Secara parsial peranan Kelompok Tani memiliki peran utama dalam meningkatkan pembangunan perikanan budidaya di Kabupaten Kampar yakni sebesar 19,94\%, Hal ini merupakan suatu kondisi yang bisa dimanfaatkan pemerintah untuk memanfaatkan kelompok masyarakat, guna memacu pertumbuhan perikanan,Kemudian disusul Dinas Perikanan Kabupaten Kampar sebesar $14,75 \%$, selanjutnya Pengurus RT/RW sebesar $13.29 \%$, kemudian peran Badan Perencanaan Pembangunan Daerah Kabupaten Kampar 11.06\%, Tokoh masyarakat sebesar 9,97\%, Kementerian Kelautan dan Perikanan RI sebesar 9,83\%, Badan Perencanaan Pembangunan Nasional RI sebesar 7,86\%, Dinas Koperasi Kabupaten Kampar sebesar 7,37\%, dan terakhir peran Kementerian Koperasi dan UKM RI sebesar 5,90\%. Untuk melihat hasil simulasi kenaikan peran masyarakat dan sensitifitasnya terhadap stakeholder yang lain dapat dilihat pada Gambar 7 berikut

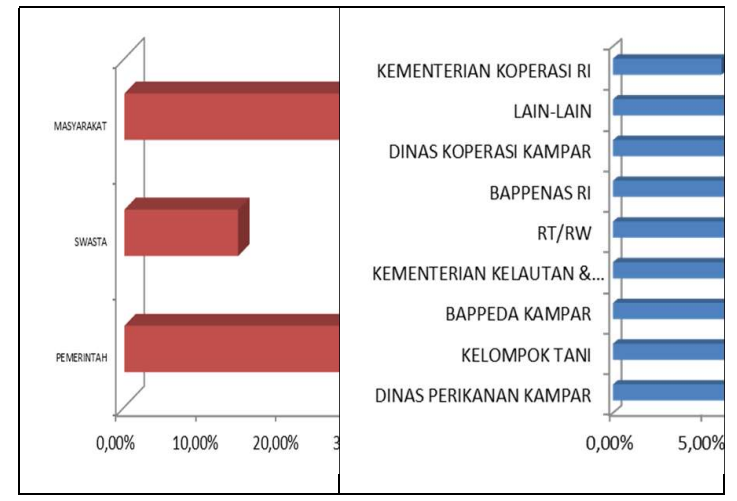

Gambar 7. Hasil Analisis Simulasi Sinergitas Peran Masyarakat Dinaikkan 10\% dan sensitifitasnya terhadap peran stakeholder lain (Sumber : Expert Choice 9.0)

\section{Simulasi Sinergitas Peranan Masyarakat diturunkan 10\%}

Hasil analisis sensitivitas, apabila peran masyarakat diturunkan $10 \%$ maka peran pemerintah mengalami kenaikan dari $50,00 \%$ menjadi $57,70 \%$ dan swasta mengalami kenaikan dari $16.67 \%$ menjadi
19.24\%. Peningkatan peran pemerintah terjadi karena adanya kenaikan peran Dinas Perikanan Kabupaten Kampar dari $17.31 \%$ menjadi $20.00 \%$, Badan Perencanaan Pembangunan Daerah Kabupaten Kampar dari 12,98\% menjadi $14.99 \%$, Kementerian Kelautan dan Perikanan RI dari $11,54 \%$ menjadi 13,33\%, Badan Perencanaan Pembangunan Nasional RI dari 9.23\% menjadi $10.66 \%$, Dinas Koperasi Kabupaten Kampar dari 8,65.1\% menjadi $10,00 \%$, dan Kementerian Koperasi dan UKM RI dari $6,92 \%$ menjadi $8,00 \%$.

\section{Analisis SWOT \\ Identifikasi Faktor Internal dan Faktor Eksternal (SWOT)}

Pemanfaatan berbagai peluang dalam upaya pengembangan perikanan budidaya di Kabupaten Kampar hendaknya memperhatikana ketentuan dan aturan yang sudah ada. Selain itu juga memerlukan strategi pengelolaan yang baik dan tepat agar bisa mencapai tujuan yang ditetapkan. Berdasarkan hal tersebut maka perlu melakukan analisa faktorfaktor internal dan ekternal yang dimiliki oleh Kabupaten Kampar. Faktor-faktor internal terdiri dari kekuatan (strength) dan Kelemahan (weakness) dalam pengembangan budidaya perikanan di Kabupaten Kampar. Faktor-faktor ekternal terdiri dari Peluang (Opportunity) dan Ancaman (Treat).

\section{Faktor Internal (S-W) a. Faktor Kekuatan (Strengths)}

Faktor kekuatan dalam pembangunan perikanan budidaya di Kabupaten Kampar antara lain Sumberdaya Lahan, Sumberdaya Manusia, Teknologi Tepat Guna yang tersedia, Kebijakan/komitmen pemerintah, dan Lembaga Pendukung. Hasil analisis terhadap faktor-faktor kekuatan dalam pembangunan perikanan budidaya dikabupaten Kampar berdasarkan kuisioner yang disebarkan kepada beberapa komponen masyarakat baik 
pelaku usaha perikanan, tokoh masyarakat, pengambil kebijakan. Dari hasil pendapat responden dalam pembangunan perikanan budidaya di kabupaten Kampar dapat diambil (5) lima nilai tertinggi, nilai prioritas faktor kekuatan dalam pembangunan perikanan budidaya dapat dilihat Tabel 2 .

Tabel 2. Nilai Faktor Kekuatan (Strengths)

\begin{tabular}{lll}
\hline No & Faktor-Faktor Kekuatan & Nilai \\
\hline 1 & Sumberdaya Lahan & 0,669 \\
2 & Sumberdaya Manusia & 0,588 \\
3 & $\begin{array}{l}\text { Teknologi Tepat Guna yang } \\
\text { tersedia }\end{array}$ & 0,556 \\
4 & $\begin{array}{l}\text { Kebijakan/komitmen } \\
\text { pemerintah }\end{array}$ & 0,644 \\
5 & Lembaga Pendukung & 0,475 \\
\hline \multicolumn{2}{l}{ Sumber $:$ Data Primer tahun 2017 }
\end{tabular}

Berdasarkan Tabel 2, kekuatan utama pada pembangunan perikanan budidaya di Kabupaten Kampar ini adalah Sumberdaya Lahan dengan nilai sebesar 0,669 , hal ini sesuai dengan data statistik Dinas Perikanan Kabupaten Kampar pada tahun 2016, dari potensi yang tersedia sebesra 6,521,30 Ha, baru dimanfaatkan seluas 911,64 Ha atau sekitar 13,98\% dengan rincian : budidaya kolam yang tersedia yaitu 6.113 Ha baru dimanfaatkan sebesar 863,51 $\mathrm{Ha}$ atau 14,13\% Sementara itu, potensi budidaya Keramba/Jaring Apung sebesar 410,00 Ha baru dimanfaatkan 48,13 Ha atau sekitar $11,74 \%$. Sumberdaya Manusia Pembudidaya dengan nilai 0,558 , sumberdaya manusia dalam kekeuatan adalah adanya pelaku usaha perikanan yang berpendidikan SLTA dan strata satu, dan memberikana Dampak yang besar dalam penegembangan perikanan kabupaten Kampar, sehingga petani dalam menjalankan usahanya sudah tertata dan sudah bersifat modern. Ketersediaan Teknologi Tepat Guna di bidang Perikanan dengan nilai 0,556 , dukungan Kebijakan/komitmen Pemerintah sebesar 0,644 , dan adanya lembaga pendukung sebesar 0,475. Kebijakan dan komitmen pemerintah kabupaten Kampar dalam memajukan perikanan sudah membuahkan hasil, namun sesuai dengan pembahasan pada pokok tujuan kedua penelitian bahwa dalam sinergitas pembangunan masih terjadinya tumpang tindah dalam pembagian tugas, dan masih terjadi gesekan antara instansi sehingga bisa menghambat kebijakan yang sudah dijalankan. Sehingga disini diharapkan dalam memnjalankan kebijakan pemerintah hendaknya bisa memanfaatkan Sumberdaya sebagai kekuatan yang bisa dimanfaatkan.

\section{b. Faktor Kelemahan (Weakness)}

Faktor-faktor kelemahan pada pembangunan perikanan budidaya di Kabupaten Kampar meliputi Pemasaran Hasil yang masih terbatas \& Keragaan Pasca Panen yang masih rendah, Permodalan, Infrastruktur, Penguasaan Teknologi, Koordinasi. Hal ini berkaitan dengan penanganan perikanan di bahagian hilir, maupun bahagian Hulu yang harus menjadi perhatian pemerintah kabupaten Kampar Hasil analisis terhadap faktorfaktor kelemahan ini ditunjukkan pada Tabel 3..

Tabel 3. Nilai Faktor Kelemahan (Weakness)

\begin{tabular}{llc}
\hline No & Faktor-Faktor Kelemahan & Nilai \\
\hline 1 & $\begin{array}{l}\text { Pemasaran Hasil \& Keragaan } \\
\text { penanganan Pasca Panen }\end{array}$ & 0,438 \\
2 & Permodalan & 0,363 \\
3 & Infrastruktur & 0,494 \\
4 & Penguasaan Teknologi & 0,394 \\
5 & Koordinasi & 0,406 \\
\hline
\end{tabular}

Sumber : Data Primer, Tahun 2017

Berdasarkan Tabel 3, kelemahan utama pada pembangunan perikanan budidaya di Kabupaten Kampar ini adalah Pemasaran Hasil \& Penanganan Pasca Panen dengan nilai 0,438 , Permodalan dengan nilai 0,363 , Infrastruktur dengan nilai 0,494, Penguasaan Teknologi dengan nilai 0,394, dan Koordinasi bernilai 0,406 .

\section{Faktor Eksternal (O-T)}

\section{a. Faktor-Faktor Peluang (Opportunity)}

Faktor-faktor peluang pada pembangunan perikanan budidaya di Kabupaten Kampar meliputi Pangsa pasar 
yang masih terbuka, Pertumbuhan Ekonomi terus meningkat, Potensi industri berbasis Sumberdaya Perikanan, Segmentasi konsumen beragam, Kebijakan Pemerintah (Pusat, Provinsi, dan Kabupaten). Hasil analisis terhadap faktor-faktor kelemahan ini ditunjukkan pada Tabel 4.

Tabel 4. Nilai Faktor Peluang (Opportunity)

\begin{tabular}{lll}
\hline No & Faktor-Faktor Peluang & Nilai \\
\hline 1 & $\begin{array}{l}\text { Pangsa pasar yang masih } \\
\text { terbuka }\end{array}$ & 0,644 \\
2 & $\begin{array}{l}\text { Pertumbuhan Ekonomi terus } \\
\text { meningkat }\end{array}$ & 0,513 \\
3 & $\begin{array}{l}\text { Potensi industri berbasis } \\
\text { Perikanan }\end{array}$ & 0,438 \\
4 & $\begin{array}{l}\text { Segmentasi konsumen } \\
\text { beragam }\end{array}$ & 0,450 \\
5 & $\begin{array}{l}\text { Kebijakan Pemerintah (Pusat, } \\
\text { Provinsi, dan Kabupaten) }\end{array}$ & 0,519 \\
\hline
\end{tabular}

Sumber : Data Primer, Tahun 2017

Berdasarkan Tabel 4, peluang utama pada pembangunan perikanan budidaya di Kabupaten Kampar ini adalah Pangsa pasar yang masih terbuka dengan nilai 0,644, Pertumbuhan Ekonomi terus meningkat dengan nilai 0,513 , Potensi industri berbasis Sumberdaya Perikanan dengan nilai 0,438, Segmentasi konsumen beragam dengan nilai 0,450 , Kebijakan Pemerintah (Pusat, Provinsi, dan Kabupaten) dengan nilai 0,513

\section{b. Faktor-FaktorTantangan (Threatment)}

Faktor-faktor

tantangan

(Treatment) pada program pembangunan perikanan budidaya di Kabupaten Kampar meliputi Bencana Alam, Ekonomi Global (persaingan pasar), Krisis Ekonomi, Keamanan, Kebijakan Ekonomi Pemerintah. Hasil analisis terhadap faktor-faktor Tantangan (Treatment) sudah diolah menghasilkan nilai dalam faktor-faktor Tantangan sebagai mana di tunjukkab pada Tabel 5.

\begin{tabular}{lll}
\multicolumn{3}{l}{ Tabel 5. Nilai Faktor Tantangan (Threatment) } \\
\hline No & Faktor-Faktor Tantangan & Nilai \\
\hline 1 & Bencana Alam & 0,369 \\
2 & Ekonomi Global (persaingan pasar) & 0,413 \\
3 & Krisis Ekonomi & 0,469 \\
4 & Keamanan & 0,463 \\
5 & Kebijakan Ekonomi Pemerintah & 0,681 \\
\hline \multicolumn{2}{c}{ Sumber : Data Primer, Tahun 2017 }
\end{tabular}

Berdasarkan Tabel 5, tantangan utama pada pembangunan perikanan budidaya di Kabupaten Kampar ini adalah Bencana Alam memperoleh nilai 0,369, hal ini berkaitan dengan keadaan iklaim yang terjadi sepanjang tahun. Bencana alam ini bisa berupaya Bajir, yang terjadi setiap tahunnya, hal ini bisa diatasi dengan memperhatikan siklus Budidaya perikanan yang harus mempertimbangkan keadaan iklim, sehingga bisa memanalisir resiko yang akan terjadi. Ekonomi Global (persaingan pasar) memiliki nilai 0,413 , Krisis Ekonomi mendapat nilai 0,469, Keamanan bernilai 0,463, dan Kebijakan Ekonomi Pemerintah mendapat nilai 0,681,(kenaikan harga BBM, penarikan subsidi)

\section{Pembuatan Matriks SWOT}

Matriks SWOT merupakan matriks matching tool yang membantu untuk mengembangkan empat tipe strategi untuk penyempurnaan strategi baru dalam pengembangan pembangunan perikanan budidaya di Kabupaten Kampar. Strategistrategi tersebut yaitu strategi SO (Strenghts-Opportunity), WO (WeeknesOpportunity), ST (Strenghts-Treatment) WT untuk masing-masing tipe strategi ditunjukkan pada Gambar 8. 
Yusrizal, Berkala Perikanan Terubuk, Vol 46. No.2. Juli (2018) Hal. 66 - 79

\begin{tabular}{|c|c|c|}
\hline & $\begin{array}{l}\text { KEKUATAN (Strengths) - S } \\
\text { c. Sumberdaya lahan kolam } \\
\text { d. Sumberdaya manusia } \\
\text { e. Teknologi tepat guna yang } \\
\text { tersedia } \\
\text { f. Kebijakan/komitmen } \\
\text { pemerintah ( Pemkab) } \\
\text { g. Lembaga pendukung }\end{array}$ & $\begin{array}{l}\text { KELEMAHAN (Weaknesses) - } \\
\text { W } \\
\text { h. Pemasaran dan penanganan } \\
\text { pasca penen } \\
\text { i. Pemodalan } \\
\text { j. Infrastrutur } \\
\text { k. Penguasaan teknologi } \\
\text { l. Koordinasi }\end{array}$ \\
\hline $\begin{array}{ll}\text { PELUANG (Opportunities) - } \\
\text { O } \\
\text { 1. Pangsa Pasar masih } \\
\text { terbuka } \\
\text { 2. Pertumbuhan ekonomi } \\
\text { 3. Potensi industri berbasis } \\
\text { sumberdaya perikanan } \\
\text { 4. Segmentasi konsumen } \\
\text { beragam } \\
\text { 5. Kebijakan Pemerintah } \\
\text { (Pusat, Provinsi, } \\
\text { Kabupaten) }\end{array}$ & $\begin{array}{l}\text { STRATEGI SO } \\
\text { SO }\left(\mathrm{S}_{\mathrm{n}} \mathrm{O}_{\mathrm{n}}\right) \\
\text { - Pemerintah bisa } \\
\text { memanfaatkan sumberdaya } \\
\text { lahan untuk mengisi pangsa } \\
\text { pasar yang masih terbuka } \\
\text { - Pemerintah Membuat } \\
\text { komitmen/kebijakan untuk } \\
\text { mengisi pangsa pasar yang } \\
\text { masih tersedia }\end{array}$ & $\begin{array}{l}\text { STRATEGI WO } \\
\text { WO }\left(\mathrm{W}_{\mathrm{n}} \mathrm{O}_{\mathrm{n}}\right) \\
\text { - Pemerintah bisa memanfaatkan } \\
\text { lembaga pendukung untuk } \\
\text { mengisis pangsa pasar yang } \\
\text { masih terbuka }\end{array}$ \\
\hline $\begin{array}{ll}\text { ANCAMAN (Threats) }-\mathbf{T} \\
\text { 1. } \\
\text { 2. } & \text { Ekoncana Alam } \\
& \text { (persaingan) } \\
\text { 3. } & \text { Krisis Ekonomi } \\
\text { 4. } & \text { Keamanan } \\
\text { 5. } & \text { Kebijakan Ekonomi } \\
& \text { Pemerintah (pusat) }\end{array}$ & \begin{tabular}{|l} 
STRATEGI ST \\
ST $\left(\mathrm{S}_{\mathrm{n}} \mathrm{T}_{\mathrm{n}}\right)$ \\
- Pemerintah bisa \\
memanfaatkan sumberdaya \\
manusia untuk mengatasi \\
kebijakan ekonmi \\
pemerintah
\end{tabular} & $\begin{array}{l}\text { STRATEGI WT } \\
\text { WT }\left(\mathrm{W}_{\mathrm{n}} \mathrm{T}_{\mathrm{n}}\right) \\
\text { - Pemerintah bisa } \\
\text { memanfaaatkan infrastruktur } \\
\text { untuk mengahdapi bencana alam }\end{array}$ \\
\hline
\end{tabular}

Strategi SO adalah menggunakan kekuatan internal pembangunan perikanan budidaya di Kabupaten Kampar untuk meraih peluang-peluang yang ada diluar. Strategi WO adalah memperkecil kelemahan-kelemahan internal pembangunan perikanan budidaya di Kabupaten Kampar dengan memanfaatkan peluang-peluang eksternal. Strategi ST adalah perikanan budidaya berusaha untuk menghindari atau mengurangi dampak dari ancaman-ancaman eksternal. Terakhir, strategi WT adalah merupakan taktik untuk bertahan dengan cara mengurangi kelemahan internal serta menghindari ancaman.

\section{Pembuatan Matrik Grand Strategy} Matrik Grand Strategy digunakan untuk menentukan apakah pihak yang berkepentingan ( stakeholder) akan memanfaatkan posisi yang kuat guna mengatasi masaalah dalam pembangunan perikanan budidaya di Kabupaten Kampar. Berdasarkan hasil perhitungan pada Penilaian Bobot Faktor Strategis Internal dan Ekstrenal di dapatkan hasil penjumlahan sumbu $X=4,08$ dan sumbu $\mathrm{Y}=3.93$ dan apabila di konversikan sumbu $\mathrm{X}$ menjadi $=0,41$ sedangkan sumbu $\mathrm{Y}=0,39$. Apabila nilai tersebut di plot ke Matrik Grand Strategy berada pada kuadran 1. (Gambar 9)

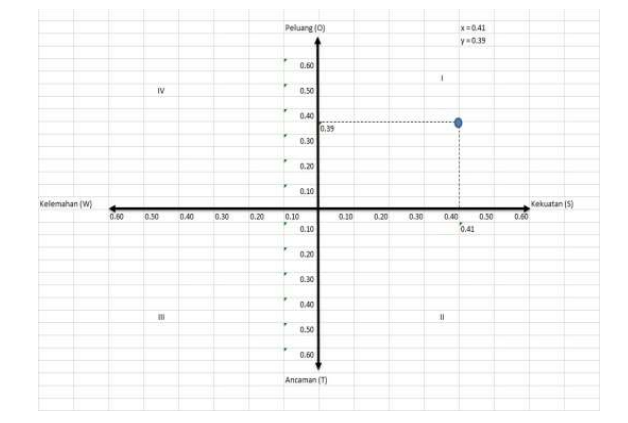

Gambar 9 : Grand Matriks Strategi Pembangunan Perikanan Budidaya Kabupaten Kampar

Menurut Rangkuti (2006), strategi yang harus dilakukan sesuai kuadran I adalah strategi agresif (Growth Oriented Strategy) atau disebut juga strategi S-O 
(Strength-Opportunities) yaitu pengembangan perikanan budidaya pada segmen tertentu secara intensif dan lebih luas. Pada situasi ini merupakan situasi yang sangat menguntungkan karena memiliki peluang dan kekuatan sehingga dapat memanfaatkan peluang yang ada.

Dari hasil Matrik Grand Strategy dapat di tarik kesimpulan bahwa dalam pengembangan perikanan budidaya Kabupaten Kampar pemerintah bisa memanfaatkan strategi S-O. yaitu :

a. Pemanfaatan lahan budidaya untuk mengisi pangsa pasar yang masih tersedia.

b. Kebijakan/komitmen pemerintah dengan pangsa pasar yang tersedia.

c. Sumberdaya Manusia dengan pangsa pasar yang masih terbuka

d. Teknologi tepat guna yang tersedia dengan pangsa pasar yang masih terbuka

e. Sumberdaya lahan dengan pertumbuhan ekonomi terus meningkat

f. Kebijkan/komitmen pemerintah dengan pertumbuhan ekonomi yang terus meningkat.

\section{Prioritas Strategi}

Dalam menentukanan prioritas strategi pembangunan perikanan budidaya di Kabupaten Kampar Terlebih dahulu dilakukan pengolahan data persepsi dan jawaban responden terhadap kondisi pembangunan perikanan budidaya di Kabupaten Kampar. Nilai dan bobot persepsi/jawaban responden ini dikonversikan ke dalam matriks SWOT. Matriks berpasangan dari masing-masing komponen dalam faktor SWOT menghasilkan nilai-nilai strategis. Nilainilai dari simulasi matriks SWOT ini dirangking mulai dari rangking tertinggi hingga rangking terendah. Berdasarkan langkah tersebut diatas di dapatkan 10 (sepuluh) dengan nilai tertinggi, strategistrategi ini dapat direkomendasikan menjadi kebijakan dalam peningkatan pembangunan perikanan budidaya di Kabupaten Kampar untuk masa yang akan datang. Untuk melihat nilai hasil simulasi matriks SWOT ini dapat dilihat pada Tabel 6.

Tabel 6. Nilai Prioritas Strategi Baru dalam Peningkatan Pembangunan Perikanan budidaya di Kabupaten Kampar

\begin{tabular}{|c|c|c|}
\hline No & Strategi & Nilai \\
\hline & Sumberdaya Lahan dengan Pangsa & 0,431 \\
\hline 1 & Pasar yang tersedia (SO) & \\
\hline 2 & $\begin{array}{l}\text { Kebijakan/komitmen pemerintah } \\
\text { dengan Pangsa Pasar yang tersedia } \\
\text { (SO) }\end{array}$ & 0,414 \\
\hline & Manusia dengan & 0,400 \\
\hline 3 & $\begin{array}{l}\text { Kebijakan Ekonomi Pemerintah } \\
\text { (ST) }\end{array}$ & \\
\hline & $\begin{array}{llr}\text { Teknologi } & \text { Tepat } & \text { Guna yang } \\
\text { tersedia } & \text { dengan } & \text { Kebijakan }\end{array}$ & 0,379 \\
\hline 4 & Ekonomi Pemerintah (ST) & \\
\hline 5 & $\begin{array}{l}\text { Sumberdaya Manusia dengan } \\
\text { Pangsa pasar yang masih terbuka } \\
\text { (SO) }\end{array}$ & 0,378 \\
\hline 6 & $\begin{array}{l}\text { Teknologi Tepat Guna yang } \\
\text { tersedia dengan Pangsa pasar yang } \\
\text { masih terbuka (SO) }\end{array}$ & 0,358 \\
\hline & Sumberdaya & 0,347 \\
\hline 7 & $\begin{array}{l}\text { Kebijakan Pemerintah (Pusat, Prov, } \\
\text { dan Kab) (SO) }\end{array}$ & \\
\hline 8 & $\begin{array}{llr}\text { Sumberdaya } & \text { lahan } & \text { dengan } \\
\text { Pertumbuhan } & \text { Ekonomi } & \text { terus } \\
\text { meningkat (SO) } & & \end{array}$ & 0,343 \\
\hline 9 & $\begin{array}{l}\text { Kebijakan/komitmen pemerintah } \\
\text { dengan Pertumbuhan } \\
\text { terus meningkat (SO) }\end{array}$ & 0,330 \\
\hline 10 & $\begin{array}{l}\text { Lembaga Pendukung dengan } \\
\text { Pangsa pasar yang masih terbuka } \\
\text { (WO) }\end{array}$ & 0,318 \\
\hline
\end{tabular}

Sumber : Data Olahan SWOT

\section{KESIMPULAN}

Hasil analisis Implementasi pembangunan perikanan budidaya di kabupaten Kampar selama 5 (lima) tahun anggaran terealisasi $55.89 \%$ dengan jumlah anggaran Rp 57,594 Miliyar dengan jumlah kegiatan 265, masih tergolong kurang memuaskan, dengan predikat C. hal ini disebabkan oleh berbagai faktor ; Pertama kepentingan yang di anggap prioritas pada saat tertentu namun tidak di masukkan dalam rencana awal sehingga terjadilah perubahan rencana kegiatan. Kedua Terjadinya Tarik ulur kepentingan dari berbagai pihak, baik eksekutif maupun legeslatif, sehingga program tidak berjalan dengan normal 
dari yang direncanakan, Tiga ketersedian anggaran daerah.

Hasil analisis sinerginitas pembangunan perikanan budidaya di kabupaten Kampar di dukung oleh faktor kesesuaian lahan budidaya dengan bobot nilai $50.00 \%$ (kesesuaian lahan $24.00 \%$, Luas lahan mencukupi $16.00 \%$, tata cara pengelolaan lahan $12.00 \%$, status kepemilikan lahan $8,00 \%$, tata cara pengelolaan air $6.00 \%$ ). Sumberdaya ekonomi dengan bobot nilai $12.00 \%$, faktor sumberdaya sosial $8.00 \%$. Kemudian sinerginitas stakeholder dalam pencapaian tujuan pembangunan perikanan budidaya di dukung oleh peran pemerintah dengan bobot nilai $50.00 \%$ (pemerintah kabupaten Kampar 25.00\%, usat $16,70 \%$, pemprov $8.30 \%$ ), Masyarakat 33.3\% (kelompok 15.39\%, RT/RW 10.26\%, Tokoh masyarakat $7.70 \%$ ), dan Swasta $16.70 \%$ Hasil analisis strategi pembangunan perikanan budidaya berada pada kuadran I (satu) yang berarti pemerintah bisa menggunakan strategi S-O (StrengthOpportunities) dengan memperhatikan 10 (sepulah) nilai prioritas tertinggi. Sumberdaya Lahan dengan Pangsa Pasar yang tersedia (0,431), Kebijakan/komitmen pemerintah dengan Pangsa Pasar yang tersedia $(0,414)$, Sumberdaya Manusia dengan Kebijakan Ekonomi Pemerintah $(0,400)$, Teknologi Tepat Guna yang tersedia dengan Kebijakan Ekonomi Pemerintah $(0,379)$ Sumberdaya Manusia dengan Pangsa pasar yang masih terbuka $(0,378)$, Teknologi Tepat Guna yang tersedia dengan Pangsa pasar yang masih terbuka $(0,358)$, Sumberdaya lahan dengan Kebijakan Pemerintah (Pusat, Prov, dan $\mathrm{Kab})$ (0,347), Sumberdaya lahan dengan Pertumbuhan Ekonomi yang terus meningkat $(0,343)$, Kebijakan/komitmen pemerintah dengan Pertumbuhan Ekonomi terus meningkat (0,330), Lembaga Pendukung dengan Pangsa pasar yang masih terbuka $(0,318)$

\section{SARAN}

Dalam pembangunan perikanan budidaya di Kabupaten Kampar pemerintah hendaknya bisa membuka usaha diversifikasi produk, membuka akses industrilisasi perikanan, dan menggiatkan program dana bergulir dengan pendampingan dari tenaga ahli sehingga bisa memanfaatkan potensi perikanan yang masih besar. Kemudian penelitian ini bisa di lanjutkan dengan melihat faktor strategi sinerginitas dalam pembangunan perikanan.

\section{DAFTAR ACUAN}

Bryson, J. M. 2008. Perencanaan Strategis Bagi Organisasi Sosial (Strategic Planning For Public and NonProfit Organization; A Guide Strengthening and Sustaining Organizational Achievement) Diterjemahkan oleh M. Miftahuddin. Cet 9. Yogyakarta. Pustaka Pelajar.

Silalahi, Ulbert. 2011. Asas-asas Manajemen. Bandung: Refika Aditama

Rangkuti, F. 2006. Analisis SWOT. Teknik Membedah Kasus Bisnis . Reorientasi Konsep Perencanaan Strategis untuk Menghadapi Abad 21) . PT. Gramedia Pustaka Utama. Jakarta.

Rangkuti F. 2004. Analisis SWOT Tehnik Membedahkan Kasus Bisnis. Jakarta PT. Gramedia Pustaka Utama. Jakarta.

M. Ghufran H. Kordi K,. Pengelolaan Perikanan Indonesia ( catatan mengenai potensi, permasalahan dan prospeknya. Cet 1. Penerbit pustaka baru press. 2015

\section{Email :}

Zulnuzula@gmail.com

Darwis.an@lecturer .unri.ac.id

yusrizal@yahoo.co 